\title{
EFFECT OF AMMONIUM HEXAFLUOROSILICATE ON INHIBITING GROWTH OF VEILLONELLA PARVULA
}

\author{
ASBY NIA ANNISA, TUTWURI ANDAJANI, AGOENG TJAHAJANI SARWONO* \\ Department of Oral Biology, Faculty of Dentistry, Universitas Indonesia, Jakarta, Indonesia. Email: agoengtjahajani@yahoo.co.id
} Received: 21 April 2017, Revised and Accepted: 18 August 2017

ABSTRACT

Objectives: This study analyzes the effects of ammonium hexafluorosilicate (AHF) on Veillonella parvula.

Methods: In this in vitro study, solutions of $\mathrm{NaF}$ (25\%, 50\%, and 100\%), AHF (25\%, 50\%, and 100\%), and SDF (38\%) were applied to solid medium cultures of V. parvula and Streptococcus mutans. The disc diffusion method was used for testing bacterial sensitivity.

Results: AHF was less effective than SDF but more effective than NaF for inhibiting growth of bacteria.

Conclusions: AHF could be effective for inhibiting the growth of V. parvula without the side effects of SDF.

Keywords: Arrested caries product, Streptococcus mutans, Veillonella parvula.

(C) 2017 The Authors. Published by Innovare Academic Sciences PvtLtd. This is an open access article under the CC BY license (http://creativecommons. org/licenses/by/4. 0/) DOI: http://dx.doi.org/10.22159/ijap.2017.v9s1.02

\section{INTRODUCTION}

Reports from Basic Health Research (RISKESDAS) state that the prevalence of caries in Indonesia is $72.1 \%$ [1]. Dental caries continues to be a global health problem, affecting humans of all ages, particularly children where caries disease is on the rise [2]. The caries process can begin at an early age immediately after a tooth erupts in the oral cavity. Caries suffered by infants and children under 5 years old is defined as early childhood caries (ECC). The prevalence of ECC in the United States is $90 \%$, while in Thailand and Indonesia it is $82.8 \%$ and $81.2 \%$, respectively [3]. ECC is caused by prolonged use of baby bottles or breastfeeding. ECC typically occurs in a short period, involves several teeth at once, and causes many teeth to turn a white or yellowish [4]. Previous study found that parents usually do not maintain proper dietary habits for their children which may lead to the increased incidence of caries in childhood [5].

In Indonesia, fluoride has been used to prevent caries. While one fluoride preparation used is natrium fluoride $(\mathrm{NaF})$, previous research has shown that the combination of fluoride and silver in the form of silver diamine fluoride (SDF) is more effective in preventing childhood caries in enamel and stopping the progression of disease to dentin. However, problems have arisen from the use of SDF, such as tooth discoloration and metal aftertaste [6]. Tooth discoloration caused by SDF can be avoided use of an ammonium hexafluorosilicate (AHF) preparation. However, there is no adequate research regarding the effect of AHF on oral bacteria. Therefore, this research will study the effect of AHF on inhibiting the growth of Veillonella parvula.

\section{METHODS}

The experiments in this research used an in vitro method for testing the effects of fluoride solutions on the growth of bacteria. The samples used were V. parvula (ATCC 10790) and Streptococcus mutans (ATCC 25175). All tools used were prepared and sterilized using an autoclave at $121^{\circ} \mathrm{C}$ for 15 minutes.

\section{Seeding media preparation}

Brain heart infusion (BHI) broth

To prepare the BHI broth, $37 \mathrm{~g}$ of $\mathrm{BHI}$ was prepared in an Erlenmeyer tube filled with $1000 \mathrm{ml}$ aquades. After the BHI completely dissolved, the Erlenmeyer tube was closed with cotton, and the entrance was covered with aluminum foil. The tube was then sterilized using an autoclave for 15 minutes. Finally, $4 \mathrm{ml}$ of vitamin $\mathrm{K}$ solution was added, and the tube was refrigerated at $4^{\circ} \mathrm{C}$. To breed V. parvula in the prepared BHI broth medium, a reaction tube, an Eppendorf pipette, and disposable tips sized $1000 \mu \mathrm{L}$ and $200 \mu \mathrm{L}$ were sterilized and prepared. The V. parvula and S. mutans bacteria stock was then moved from an $-80^{\circ} \mathrm{C}$ refrigerator into a cool box filled with ice. Next, $10 \mathrm{ml}$ of BHI broth was moved into two reaction tubes using a micropipette and disposable tips sized $1000 \mu \mathrm{L}$. $10 \mu \mathrm{L}$ each of $V$. parvula and $S$. mutans were taken using disposable tips sized $200 \mu \mathrm{L}$ and poured into a reaction tube-containing BHI broth. The reaction tube was closed with cotton and sealed in a zipper bag filled with a gas pack. The tube was then incubated for $24 \mathrm{hrs}$ at $37^{\circ} \mathrm{C}$.

\section{BHI agar}

To prepare the BHI agar, $37 \mathrm{~g}$ of $\mathrm{BHI}$ powder and $13 \mathrm{~g}$ of Bacto agar were used. The BHI and agar were dissolved in an Erlenmeyer tube-containing $1000 \mathrm{ml}$ of aquades. After the solution was completely dissolved, the Erlenmeyer tube was closed with cotton, and the top was covered with aluminum foil. The tube was sterilized using an autoclave and chilled until $50^{\circ} \mathrm{C}$. Then, $20 \mathrm{ml}$ of BHI agar solution was poured into a petri dish and set aside until it hardened. It was refrigerated at $4^{\circ} \mathrm{C}$. To breed V. parvula in the agar medium, the following items were prepared: A sterilized micropipette; the BHI agar medium; inoculating loops; and V. parvula and S. mutans bacteria. A Bunsen burner was used to maintain the sterility of the working environment. The neck of the tube that contained the bacteria was heated to prevent contamination. Then, the inoculating loops was heated in the Bunsen flame until it began to smolder. The heated hose was then chilled in agar. Once cooled, the hose was used to make a single etching in the BHI agar with the bacteria. Finally, the agar medium that contained the bacteria was incubated at $37^{\circ} \mathrm{C}$ for $24 \mathrm{hrs}$ in anaerobic conditions. 
Table 1: Inhibit zone diameter (mm) of AHF, NaF, and SDF for S. mutans and V. parvula breed

\begin{tabular}{lll}
\hline Solution & S. mutans & V. parvula \\
\hline NaF 25\% & 4.65 & 4.05 \\
NaF 50\% & 3.5 & 7.85 \\
NaF 100\% & 4.25 & 9.8 \\
Mean NaF & 4.13 & 7.23 \\
AHF 25\% & 8.05 & 3.9 \\
AHF 50\% & 10.95 & 4.55 \\
AHF 100\% & 7.6 & 9.45 \\
Mean AHF & 8.86 & 5.96 \\
Mean SDF 38\% & 9.55 & 10.56 \\
\hline
\end{tabular}

AHF: Ammonium hexafluorosilicate, NaF: Natrium fluoride,

S. mutans: Streptococcus mutans, V. parvula: Veillonella parvula

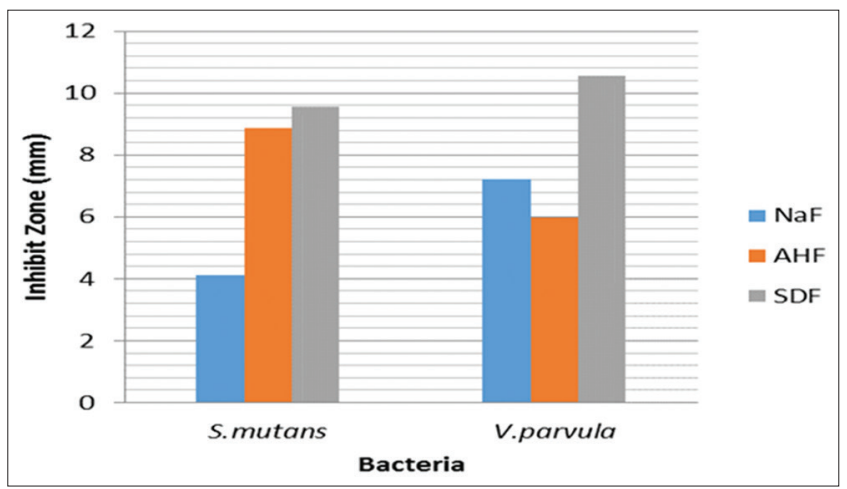

Fig. 1: Mean inhibit zone diameter around coated solution disk

Creating $\mathrm{AHF}$ and $\mathrm{NaF}$ test material in concentrations of $\mathbf{1 0 0 \% \text { , }}$ $\mathbf{5 0} \%$, and $\mathbf{2 5 \%}$

To create the AHF and NaF solutions, $1 \mathrm{ml}$ of AHF and NaF were poured inside of two Eppendorf tubes to get a $100 \%$ solution of each. Next, $0.5 \mathrm{ml}$ of each solution was poured into two Eppendorf tubes, and $0.5 \mathrm{ml}$ of aquabides was added to each to make a $50 \%$ solution. Then, $0.25 \mathrm{ml}$ of each solution and $0.75 \mathrm{ml}$ of aquabides was added to two Eppendorf tubes to get a concentration of $25 \%$. Finally, $0.03 \mathrm{ml}$ of each SDF, AHF, and $\mathrm{NaF}$ solutions $(100 \%, 50 \%$, and $25 \%)$ was spread on a blank disk. A blank disk diffusion test was performed by pouring $V$. parvula and S. mutans into a petri dish-containing BHI agar and then placing the prepared disk-containing $0.03 \mathrm{ml}$ of test material inside the petri dish containing the bacteria breed. The petri dish was then incubated in anaerobic conditions at $37^{\circ} \mathrm{C}$ for $24 \mathrm{hrs}$.

\section{Observation}

The test media was placed in a colony counter and then observed in the monitor. Zone counting mode in the colony counter monitor was activated. The inhibit zone diameter was found using the device's scan button. The same procedure was repeated for all test media.

\section{RESULTS}

Table 1 shows that the inhibit diameter zone values were greater than zero, which means that an inhibit zone was formed in all test materials and for all solution concentrations. Fig. 1 also shows mean inhibit zone diameter around coated solution disk. The results of this research also show that the SDF inhibition zone had a relatively high value.

\section{DISCUSSION}

The results shows that the inhibit diameter zone values were greater than zero, which means that an inhibit zone was formed in all test materials and for all solution concentrations. These values were the result of fluoride-containing test materials that inhibited the colonization of bacteria. As previous research has stated, fluoride solutions influence the remineralization process, and affect bacteria and plaque growth $[7,8]$. Table 1 also shows that the mean inhibit zone diameter value in AHF for $V$. parvula was greater than for S. mutans while the mean inhibit zone diameter value in SDF for $S$. mutans was greater than for V. parvula.

Based on these results, AHF more effectively inhibits $S$. mutans growth, while SDF more effectively inhibits the growth of $V$. parvula. These results, which demonstrate that silver has a better ability to inhibit bacteria than does silica, is supported by previous research that explains that the tolerance of Gram-positive bacteria to silver is higher than Gram-negative bacteria. This is due to structural differences because Gram-positive bacteria have more peptidoglycan layers in its membrane cell than gram-negative bacteria $[9,10]$.

The results of this research also show that the NaF inhibition zone had a relatively low value. The active ingredient of $\mathrm{NaF}$ is fluoride which has a diminished ability to kill bacteria without another active ingredient such as silica in AHF or silver in SDF. Again, this result is supported by previous research which showed that fluoride ion alone has less effectivity than fluoride combined with another material $[11,12]$.

\section{CONCLUSION}

This research concludes that AHF inhibits $V$. parvula growth effectively and that the most optimal inhibition was achieved in a $100 \%$ concentration of AHF. Further studies and research are suggested to examine the efficacy of AHF application beyond single-celled bacteria, and also to examine whether AHF could be used in place of SDF without the side effects.

\section{REFERENCES}

1. Badan Penelitian dan Pengembangan Kesehatan. Riset Kesehatan Dasar (RISKESDAS). Jakarta: Kementerian Kesehatan RI; 2013.

2. Vinotha T, Geetha RV. Natural remedy to prevent tooth decay: A review. Asian J Pharm Clin Res 2015;8(1):32-3.

3. Sugito FS, Djoharnas H, Darwita RR. Breastfeeding and early childhood caries (ecc) severity of children under three years old in DKI Jakarta. Makara Kesehatan 2008;12(2):86-91.

4. Zafar S, Harnekar S, Siddiqi A. Early childhood caries: Etiology, clinical considerations, consequences and management. Int Dent SA 2009;11(4):24-36

5. Shasmitha R, Shanmugaavel AK. Knowledge and responsibility of the parents toward child's oral health: A cross-sectional study. Asian J Pharm Clin Res 2017;10(1):162-6.

6. Lendrawati L. Penggunaan silver diamine fluoride $38 \%$ sebagai arresting caries treatment (ACT) pada anak-anak. Majalah Kedokteran Andalas 2001;35(2):98-105.

7. Marquis RE. Antimicrobial actions of fluoride for oral bacteria. Can J Microbiol 1995;41(11):955-64.

8. Płuciennik-Stronias M, Zarzycka B, Bołtacz-Rzepkowska E. The effects of topical fluoridation of enamel on the growth of cariogenic bacteria contained in the dental plaque. Med Dosw Mikrobiol 2013;65(2):129-32.

9. Egger S, Lehmann RP, Height MJ, Loessner MJ, Schuppler M. Antimicrobial properties of a novel silver-silica nanocomposite material. Appl Environ Microbiol 2009;75(9):2973-6.

10. Abdel-Halim ES, Al-Deyab SS. Antimicrobial activity of silver/ starch/polyacrylamide nanocomposite. Int $\mathrm{J}$ Biol Macromol 2014;68:33-8

11. Savas S, Kucukyilmaz E, Celik EU, Ates M. Effects of different antibacterial agents on enamel in a biofilm caries model. J Oral Sci 2015;57(4):367-72.

12. Gao SS, Zhang S, Mei ML, Lo EC, Chu CH. Caries remineralisation and arresting effect in children by professionally applied fluoride treatment-a systematic review. BMC Oral Health 2016;16(12):1-19. 